\title{
Effectiveness of instructional media based on interactive cd learning on basic network at vocational high school : improving student cognitive ability
}

\author{
Doni Pernanda ${ }^{1}$, Mahesi Agni Zaus ${ }^{2}$, RizkyEma Wulansari ${ }^{3}$, Syaiful Islami ${ }^{4}$ \\ ${ }^{1234}$ UniversitasNegeri Padang, Padang - Indonesia,(dpernanda@gmail.com)
}

\begin{abstract}
In the fact, students in the school were seen that most of them have low learning spirit, students were less active, because lack of using instructional media that corresponded with students characteristics in the learning process. This study aimed to know about effectiveness of instructional media based on interactive $C D$ learning that had developed. Effectiveness test was carried out by giving pretest and posttest instruments to the students. The instruments of effectiveness was using test, and the data was processed by Independent T-test formula. Instructional media based on interactive CD learning was said effective to improve students outcomes because $87,60 \%$ students had reached Minimum Mastery Criteria. Based on the result, can be concluded that instructional media based on interactive CD learning on Basic Network was effective to use as instructional media on Basic Network learning process.
\end{abstract}

Keywords: effectiveness, cd interactive, basic network

\section{Introduction}

According with development of information communication and technology, so that teacher just not must be able to benefit all of technology product that available in the market, but must be able to develop various learning sources or instructional media either based on technology or not step by step. Learning activity is a system that related to each other. The system consists of components, are follows: teacher, students, and instructional media that used in the learning process. The component related to each other to produce a goal that want to be reached in the learning process. One of the education successful is showed by students achievement that more increasing. Factor that influence about student outcomes is instructional media that used in the learning process.The instructional media and learning method that match with learning material so influence toward student outcomes (Islami S. \&Yondri S., 2016)

The using of instructional media based on interactive CD learning is media that start to be used in the learning process and can assist teacher to teach in the learning process. Instructional media if can be understood by outline is human, material or event that construct condition that make student can get knowledge, skill, and attitude, and existing media have the important meaning in the learning process(Arsyad, 2011; Djamarah, 1997). Instructional media is a technology that bring a message that 
can be used to learning necessities, instructional media is physic tool to deliver learning material, instructional media is a communication tool in the form of print and view including a hardware technology (Rusman, 2011).

The important problem now are lack of using instructional media in the learning process and generally the teacher still use conventional method, like lecture, or just use the same material book in the every learning process, that can make the learning process become monotonous and boring. Based on observation by researcher in the Vocational High School at Pariaman directly, are follows: by giving the questionnaire and interview directly toward student about the problem that they face in the vocational learning process of Multimedia expertise program, so that can be concluded that the problems they facing in the learning process are learning system that still introducing and have not learned by practical, and have not understood about the material of Basic Network, so that the student have not understood what is used or what is needed when construct a peer to peer networking or client server networking.

The aim of this study is to know about effectiveness of interactive CD learning that had be developed as instructional media in the Basic Network learning process. Instructional media can assist student to understand and apply the learning concepts, so that the learning outcome can be reached by students and instructional media has a big opportunity to close student achievement gap than students do not learn by using instructional media (Wulansari et al., 2017; Keengwe, 2012).The technique that be used in the delivering materials in instructional media effectively can increase phonological awareness in the learning process (Foster, Erickson, Forster, Brinkman, \&Torgensen, 1994; Macaruso\& Walker, 2008; Mitchell \& Fox, 2001; Reitsma\&Wesseling, 1998).Instructional media that benefit viewing and hearing are a good way to assist students in the learning process (Woo, 2009).Based on comparing with the old research, there are too much instructional media that had been developed, like development of Computer Assisted Instruction (CAI) in the English course (Keengwe, 2012) and development of Computer Assisted Instruction on the Math course (Hawkins, 2016).

Based on the problems that have explained under, this research need to be carried out as study to know the effectiveness about interactive $C D$ learning that have been developed, and to know about the effectiveness of interactive $C D$ learning to be used to increase student cognitive ability on the Basic Network learning process. Because the subject of Basic Network is practical subject that the material not enough explained by lecture only. Teacher also need how to way they can effectively integrate instructional media in the class of learning process (Christensen and Knezek, 2016).

\section{Method}

This research use Research and Development (R\&D) method. Research and Development method is a process series or steps to develop a new product or perfect a product that have been exist so that can be accounted (Trianto, 2012). The development model is used in development of this interactive CD learning is 4-D (Four-Ds) development model that developed by S. Thiagarajan et al. The Four-Ds development procedure have four steps, are follows: definition step, design step, development step, and disseminate step. Four-Ds model in each development step have activities that show about the existing of activity step order.

The instrument that used to collect the effectiveness data is test. Test is used to collect the data of student outcomes that is cognitive test, are follows pretest that carried out in the begin of learning process, and posttest that carried out in the last of learning process after using interactive CD learning. Instrument that is used to collect the media effectiveness data is test. Test is used to collect the data of student outcomes that is cognitive test, are follows pretest that carried out in the begin of learning process, and posttest that carried out in the last of learning process after using interactive CD 
learning. The question of test is the objective test in the form of multiple choice with a total of 30 items. Effectiveness test is carried out by comparing student outcomes after and before treatment using Independent T-Test.

\section{Results and Discussion}

a. Pretest Result

Data were obtained after pretest test for the studentswere analyzed using SPSS 16, to known data distribution, average value and deviation standard form data were obtained. Analysis result used SPSS form data result pretest were explained in the table 1

Table 1. Result Analyzed T-test Pretest

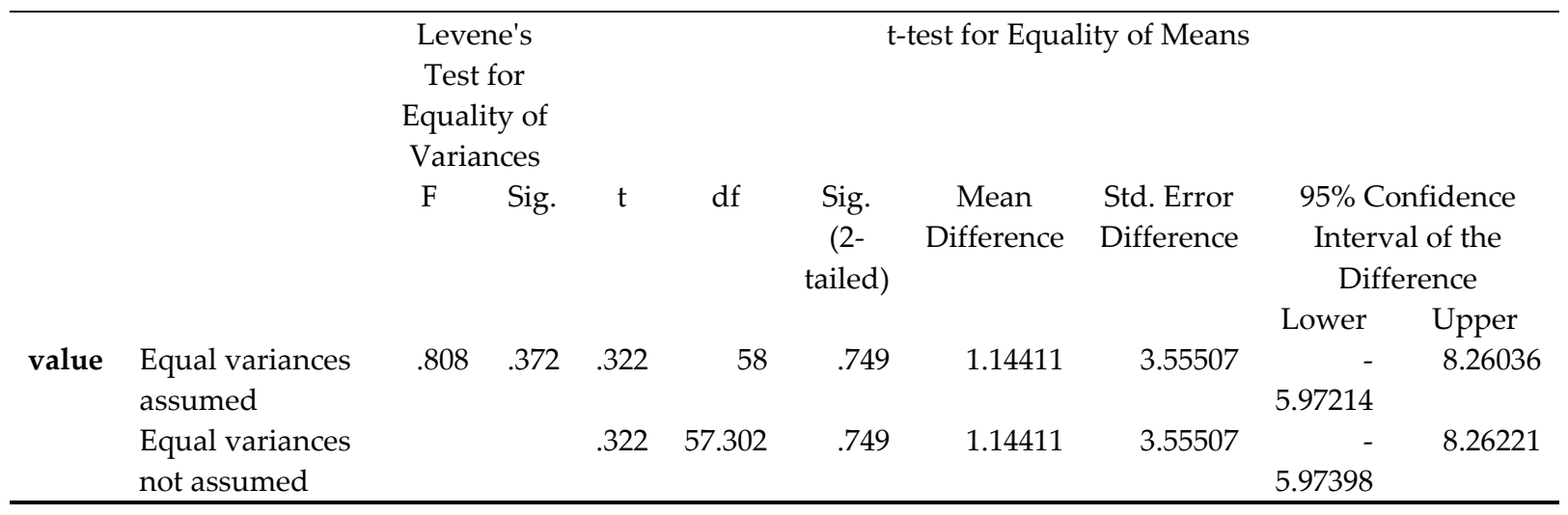

Based data resulted analyzed used SPSS 16 such were explained as presented on table 1, were known signification form sign (2-tailed) value greater than from 0,05 , so summarized there was not differenced significant between studied resulted pretest students control class and experiment class

b. Posttest Result

Data posttest value obtained after learning process basic network with using Interactive CD. The students implement the learning using interactive $C D$, then given the matter of posttest. Posttest data obtained after final test for the students then the data were analyzed using SPSS 16. Result data analyzed posttest explained on table 2.

Table 2. Analyzed Result T test Data Posttest

\begin{tabular}{|c|c|c|c|c|c|c|c|c|c|c|}
\hline \multirow{4}{*}{ value } & & \multicolumn{2}{|c|}{$\begin{array}{c}\text { Levene's Test } \\
\text { for Equality } \\
\text { of Variances }\end{array}$} & \multicolumn{7}{|c|}{ t-test for Equality of Means } \\
\hline & & F & Sig. & $\mathrm{t}$ & $\mathrm{df}$ & $\begin{array}{l}\text { Sig. } \\
(2- \\
\text { tailed })\end{array}$ & $\begin{array}{c}\text { Mean } \\
\text { Difference }\end{array}$ & $\begin{array}{l}\text { Std. Error } \\
\text { Difference }\end{array}$ & \multicolumn{2}{|c|}{$\begin{array}{l}\text { 95\% Confidence } \\
\text { Interval of the } \\
\text { Difference }\end{array}$} \\
\hline & $\begin{array}{l}\text { Equal } \\
\text { variances } \\
\text { assumed }\end{array}$ & 2.768 & .102 & 6.677 & 58 & .000 & 10.93333 & 1.63740 & $\begin{array}{c}\text { Lower } \\
7.65572\end{array}$ & $\begin{array}{c}\text { Upper } \\
14.21094\end{array}$ \\
\hline & $\begin{array}{l}\text { Equal } \\
\text { variances not } \\
\text { assumed }\end{array}$ & & & 6.677 & 49.527 & .000 & 10.93333 & 1.63740 & 7.64374 & 14.22292 \\
\hline
\end{tabular}


Based analyzed data result using SPSS 16 as were explained on the table 2, was known signification value form sig (2-tailed) value smaller form 0,05, so summarized there is a significant difference between the students' learning outcomes of the control class and the experimental class.

The basis for determining the effectiveness of this interactive $\mathrm{CD}$ is if classical completeness presentation of subjects test subjects greater than or equal to $85 \%$ then This interactive CD is effective, but otherwise, if the students' classical completeness of the test subjects is less than $85 \%$ then this interactive CD is not effectively used in Basic Networking lesson. Based on the results of data analysis that has been done, then from 30 students who were sampled in the experimental class, it was found that 28 students $(87.6 \%)$ have reached the minimum mastery criteria, this means that the students' classical learning completeness score has reached $87,6 \%$ which is greater than $85 \%$. Thus, it can be concluded that this interactive CD is effectively used on the subjects of Basic Network in Vocational High School (SMK).

\section{Conclusions}

This research has produced an interactive CD that can be used in Basic Networking study at Vocational High School. This interactive CD has passed the effectiveness test stages through the students learning achievement test, which is the pretest conducted prior to the use of interactive CD in the learning, and posttest at the end of the learning after the use of interactive $\mathrm{CD}$ in the learning process. The effectiveness test results state that this interactive $C D$ is in the effective category. This interactive $\mathrm{CD}$ can be used effectively in Basic Networking learning, because this developed interactive $\mathrm{CD}$ can improve student learning outcomes.

\section{References}

Arsyad A. (2011). Media Pembelajaran. Jakarta : PT Rajagrafindo Persada.

Christensen, R. and Knezek, G. (2016). Relationship of Mobile Learning Readiness to Teacher Proficiency in Classroom technology Integration. $13^{\text {th }}$ International Conference on Cognition and Exploratory Learning in Digital Age. pp 303-306.

Djamarah, Syaiful Bahri. (1997). Strategi Belajar Mengajar. Jakarta : Rineka Cipta.

Foster, K. C., Erickson, G. C., Forster, D. F., Brinkman, D., \&Torgensen, J. K. (1994). Computer administered instruction in phonological awareness: Evaluation of the DaisyQuestprogram. Journal of Research and Development in Education, Vol. 27, pp. 126-137.

Hawkins, R O. (2016). Using Computer-Assisted Instruction to Build Math Fact Fluency: An Implementation Guide. Intervention In School and Clinic, 1-7.

Islami, S. \&Yondri, S. (2016). PerbedaanHasilBelajarSiswadalamPembelajaranKooperatifTipe Jigsaw denganKonvensional. In National Conference of Applied Engineering, Business and Information Technology (ASNI-Tech). pp. 414-421.

Keengwe, J. (2016). Using Computer-Assisted Instruction to Enhance Achievement of English Learners. Education Information Technology, Vol. 19, pp. 295-306.

Macaruso, P., \& Walker, A. (2008). The efficacy of computer assisted instruction for advancing literacy skills in kindergarten children. Reading Psychology, Vol. 29, pp. 266-287.

Mitchell, M. J., \& Fox, B. J. (2001). The effects of computer software for developing phonological awareness in low-progress readers. Reading Research and Instruction, Vo. 40, pp. 315-332.

Reitsma, P., \&Wesseling, R. (1998). Effects of computer-assisted training of blending skills in kindergartners. Scientific Studies of Reading, Vol. 2, pp. 301-320.

Rusman et al. (2011). Pembelajaran Berbasis Teknologi Informasi dan Komunikasi. Jakarta: Rajawali Pers. 
Sugiyono. (2010). StatistikaUntukPenelitian. Bandung: Alfabeta.

Thiagarajan, S., Semmel, D.S\&Semmel, M. I. (1974). Instructional Development for Training Teachers of Exceptional Children. Minneapolis, Minnesota: Leadership Training Institute/Special Education, Uninersity of Minnesota.

Trianto. (2012). Mendesain Model PembelajaranInovatif-Progresif. Jakarta: KencanaPredana Media Group. Woo, H. L. (2009). Designing Multimedia Learning Environments Using Animated Pedagogical Agents: Factor and Issues. Journal of Computer Assisted Learning. Vol. 25, pp. 203-218.

Wulansari, R. E., Puyada, D., Wijaya, I., Rukun, K. (2017). Effectiveness Of Instructional Media Based Game On Mathematics At Vocational High School. International Journal of Research Science and Management, Vol. 4, Issue 12, pp. 125-128. 